\title{
ISSUES OF FINANCING REGIONAL DEVELOPMENT
}

Under Art. 158 of the Treaty establishing the European Community (TEC), one of the EU's main aims is to enhance the Community's social and economic cohesion, in particular by diminishing the developmental disparities between various regions, as well as eliminating the backwardness of the less privileged regions or islands, including rural areas. In order to pursue this goal, the funds accumulated in the EU budget are used, as well as supporting funds from member states, in compliance with the principle of additionality.

Cohesion policy includes financial activities aimed both at member states (by making member states eligible for support according to specific criteria), as well as at regions within these states (by making particular regions eligible for support). One of the elements of cohesion policy is regional (structural) policy. Regional policy is defined as long-term activities of public authorities in various fields, aimed at stimulating economic and social development in regions. It is the effect of deeming any disparities existing between them undesirable, whether in terms of economic or social development. The aim of this policy is to create conditions enhancing competitiveness of regions and to prevent marginalization of certain areas of the EU. The basic message of this policy is the need for a balanced economic growth throughout the EU. This policy focuses on economic and social issues. Actions aimed at supporting innovative and competitive economy have been playing an increasingly important role in cohesion policy. The policy also supports regional innovation systems.

The core of regional policy is for public authorities to impact economic and social development on the regional level. A region can be defined as a homogenous and the largest specified territory of a state's area, on the supralocal level, with a considerable number of inhabitants. We can distinguish between natural regions (usually based on social bonds, tradition or homogenous features) and artificial regions (the remaining ones, with a social and administrative character - like the Polish voivodships). 
The uniform European regional policy is based on a network of regions used by the UE. It is based on a classification of territorial units for statistical and planning purposes. The classification was made by Eurostat and the European Commission.

Currently in Poland, there are five functional levels of classification for statistic and planning purposes. Level I is created by regions - with the effect of streamlining 6 regions that include two or more voivodships, level II consists of voivodships, levels III, IV and V are local levels. Currently regional policy in Poland is conducted mainly on levels II (i.e. voivodships) and III (with the scope of several poviats districts), as the main eligibility criteria for support participation have been set on these levels.

The principles and demands of EU regional policy for the programming period 2007-2013 are specified by the Strategic Community Guidelines programmed by the European Commission and accepted by the Council, decision no 2006/702 EC, dated $6^{\text {th }}$ October 2006.

A document that is strictly related to the programming document is the National Strategic Reference Framework (NSRF), prepared by Poland and specifying the strategy for actions on the national level, aiming at implementing the Community Strategic Guidelines and allowing to coordinate the use of EU and national funds.

The main strategic aim specified by NSRF is to "create conditions allowing the growth of competitiveness of Polish economy based on knowledge and entrepreneurship, ensuring growth of employment and an improvement of the level of social, economic and spatial cohesion".

The aim of drafting such a programming document is to ensure the appropriate use of EU funds allocated to structural policy.

NSRF contains the following elements:

1) an analysis of the developmental potential, disparities and weaknesses in the context of current trends in the European and global economy,

2) a strategy of actions, including priority actions from a substantive and territorial point of view.

3) an index of operational programmes for objectives: Convergence and Regional Competitiveness and Employment,

4) a description of the way the funds within the Convergence and Regional Competitiveness and Employment objectives will contribute to implementing European Union's priorities for promoting competitiveness and creating jobs, 
5) indicative annual allocation of each of the funds into particular programmes,

6) only for regions included in the Convergence objective:

a) actions foreseen in order to improve the efficiency of a member state's administration,

b) the amount of overall annual funds allocated within EAFRD and EDF,

c) information required in order to perform ex ante verification of the additionality principle compliance;

7) with respect to member states eligible under Cohesion Fund - information on the mechanisms aiming at providing coordination between various operational programmes and between these programmes and EAFRD, EDF and - where applicable - interventions of EIB and other existing financial instruments.

\section{National Cohesion Strategy (NCS)}

(National Strategic Reference Framework NSRF) is a strategic document which specifies:

- priorities,

- areas,

- method of using,

- system of implementing EU funds within the Community budget for 200713. It was ultimately approved by the European Commission in May 2007.

The strategic objective of NCS (NSRF) is to create conditions allowing the growth of competitiveness of Polish economy based on knowledge and entrepreneurship, ensuring growth of employment and an improvement of the level of social, economic and spatial cohesion.

The strategic objective will be obtained by realizing horizontal detailed priorities. The horizontal priorities of NCS (NSRF) are:

- to improve the quality of public institutions operation and extend partnership mechanisms,

- to improve the quality of human capital and increase social cohesion,

- to develop and modernise technical and social infrastructure which is crucial for the growth of Poland's competitiveness, 
- to improve competitiveness and innovation of enterprises, including in particular the manufacturing sector with a high added value and to develop the service sector,

- to increase the competitiveness of Polish regions and to prevent their social, economic and spatial marginalization,

- to provide equal development opportunities and support structural changes in the rural areas.

NSRF is the executive plan under the Act on the Principles of Development Policy.

The activity of EU funds in member states takes the form of operational programmes within NSRF. The content of operational programmes, depending on the objective they are related to, is specified in detail by Council regulation (EC) no 1083/2006. The programmes which obtain support within cohesion policy should aim at focusing their resources on the priorities specified in the CSG (Community Strategic Guidelines).

Operational programmes constitute the basic programming document for the implementation of cohesion policy, covering the programming period, i.e. 20072013. The programmes realize the state's development strategies, sector strategies and voivodeship development strategies. For national and sector strategies, the drafting procedure and the legal form of the development strategies is specified in the Act on the Principles of Development Policy, while for voivodeship strategies the act on the local voivodeship government. The national development strategy is prepared by the relevant minister in the field of regional development in cooperation with other ministers, then, under the provisions of the act, it is adopted as an act of law (the wording used in the act is unclear). The sector strategy is prepared by the relevant minister and, together with an opinion by the minister of regional development, it is presented to the Council of Ministers, which adopts it in the form of a resolution.

The strategies for the development of voivodeships are adopted by the managing councils of the voivodships.

Under currently binding legal regulations, the operational programmes may be:

- national programmes

- regional programmes

A national operational programme which includes foreign financing is developed by the minister of regional development and adopted by the Minister of Council by way of a resolution. Such a programme is then approved by the 
European Commission and published on the internet site of the authority managing the programme.

A regional operational programme which includes foreign co-financing is adopted by the voivodship managing council in a form of a resolution. It is approved by the European Commission. The notification about the programme approval is published in the voivodeship's official journal, with reference to the relevant internet site where the content of the programme is uploaded. The act on principles of regional policy also obliges the authority managing an operational programme to quote any possible changes to the programme.

Regional operational programmes are co-financed also from the state budget. The conditions for co-financing are specified in the "Voivodeship Contract", which also constitutes the basis for forwarding the developmental subsidy from the state budget to the budget of the voivodeship local government.

22 operational programmes are being implemented in the 2007-2013 financial perspective: 6 national programmes and 16 regional programmes. The national programmes are:

- Operational Programme "Development of Eastern Poland",

- Operational Programme "Infrastructure and Environment",

- Operational Programme "Innovative Economy",

- Operational Programme "Human Capital",

- Operational Programme "Technical Cooperation",

- Operational Programme „Technical Support”.

The detailed breakdown of structural funds and Cohesion Fund in Poland with fund allocation to particular operational programmes:

- OP Infrastructure and Environment 41.9\% of all funds (EUR $27.9 \mathrm{bn}$ ),

- OP Human Capital 14.6\% of all funds (EUR 9.7 bn),

- OP Innovative Economy $12.4 \%$ of all funds (EUR 8.3 bn),

- OP Development of Eastern Poland 3.4\% of all funds (EUR 2.3 bn),

- OP Technical Assistance $0.8 \%$ of all funds (EUR 0.5 bn),

- OP European Territorial Cooperation 2\% of all funds (EUR $0.7 \mathrm{bn}$ ),

- 16 Regional Operational Programmes 24.9\% of all funds (EUR 16.6 bn). 


\section{Financing of the National Cohesion Strategy (National Strategic Reference Framework)}

The total amount devoted to the implementation of NSRF between 2007 and 2013 will amount to approximately EUR 85.6 bn. The amount of yearly expenditure related to NSRF (until 2015) will be approximately EUR 9.5 bn, which corresponds to about $5 \%$ of GDP.

\section{Out of this amount:}

- EUR 67.3 bn will come from EU budget,

- EUR 11.9 bn will come from national state funds (including approx. EUR 5.93 bn from the state budget),

- approx. EUR 6.4 bn will come from the involvement of private entities.

The cohesion policy concerning expenditures will be coordinated with expenditures targeted at structural instruments of the Common Agricultural Policy and Common Fisheries Policy, as well as with European programmes for supporting competitiveness.

Under Art. 206 of the Act of 30 June 2005 on Public Finance, operational programmes constitute an annex to the budget act. For every operational programme, the following should be specified: the managing authority, funds for the programme implementation, the state's revenue coming from EU funds inflow allocated for a particular year of budgeting and two subsequent years, expenditures for the programme implementation allocated for the given year of budgeting and two subsequent years, the state budget expenditure plan for programme co-financing (with specific breakdown into: part, division, allocation). Both funds for the programme implementation and the expenditures planned for the implementation (in a given year of budgeting and two subsequent years) should be described broken down to: EU budget funds, state budget funds, territorial government budget funds, other national public funds and other funds. Local government unit funds should be specified in the resolutions of relevant bodies constituting the territorial government units.

The Act on Public Finance also specifies deadlines for submitting relevant information by the local government units, concerning the planned budget for the implementation of operational programmes. The gmina (commune) and poviat (district) authorities present such information to the voivodeship management council by the $15^{\text {th }}$ of August. On the $31^{\text {st }}$ of August the voivodeship managing council presents all the information about funds for the operational programme implementation within the voivodeship, to the minister of regional development. 
The largest amount of funds has been allocated to the implementation of OP Infrastructure and Environment - over $40 \%$ of all funds allocated to Poland in the financial perspective 2007-2013 for cohesion policy.

In the period of the 2007-2013 financial perspective, local governments have an important role to play in the implementation of regional policy. They are responsible for preparing regional operational programmes, for adopting them, and then, as managing authorities, for their implementation. The most important powers of the voivodeship managing councils include: preparing a detailed description of the operational programme projects, preparing the proposal for selection criteria of projects eligible for co-financing, and then selecting the projects and making the payments. Their mandate also includes ensuring appropriate publicity for the operational programme.

The funds from the EU budget, allocated to the implementation of the cohesion policy (excluding funds allocated for the implementation of programmes within objective European Territorial Cooperation and European Neighbourhood and Partnership Instrument) currently constitute the state budget's revenue. Funds from Structural Funds and Cohesion Fund are forwarded by the European Commission to Poland in the form of advance payments, periodical payments and final payments, onto specific bank accounts in euros, managed by the Minister of Finance. These funds constitute the state budget revenue. Then they are forwarded from the state budget in the form of a developmental subsidy, combined with the national funds from the state budget.

The terms and conditions of forwarding subsidies are stipulated by Art. 202 and 203 of the Act on Public Finances.

The developmental subsidies can be forwarded as:

- advance payments for the implementation of the operational programme

or

- reimbursement of expenditures made for the implementation of such programmes.

The subsidy, to the voivodeship local authorities for the implementation of regional operational programmes, constitutes revenue of this voivodeship's budget. It may not be higher than the limit of the state budget expenditures allocated for financing such a programme in a given budgeting year. The voivodeship local authority, as the managing authority for the operational programme, then provides subsidies to beneficiaries of regional operational programmes.

Developmental subsidies in the form of an advance payment are paid based on a contract concluded between the disposer and the beneficiary. The content of 
such a contract is specified by Art. 209 (2) of the Act on Public Finances. These subsidies are targeted and may only be designated to implement the projects within operational programmes. They are to be accounted for according to the principles and deadlines specified in the Act on Public Finances (Art. 210 and 211 of the Act). National development subsidies paid as reimbursement of the expenses made, are transferred on the basis of a correctly submitted and approved payment claim.

The subsidies have the objective of co-financing projects selected in the competition. The rules of conducting such competitions are specified in the act on the principles of development policy.

The competitions may be cyclical or ongoing. If the competitions are held cyclically, the deadlines for application submission are set in advance, if the competition is an ongoing one, the incoming applications are examined until the limit for financing is reached.

The results of the competition are advertised on the internet site of the institution which organizes it. The successful applicants receive subsidies based on a co-financing agreement. Unsuccessful applicants have a right to appeal. A twoinstance appeal procedure has been provided for in the act on the principles of regional development, i.e. filing a complaint followed by filing a request to have the matter re-examined. The deadline for examining an appeal is one month. For regional operational programmes, the examination of a complaint is the task of the relevant voivode, and the processing an appeal is the task of the minister of regional development. The applicants do not have the right to file a complaint with the administrative tribunal, as the decision on granting or refusal of co-financing is not an administrative decision, under the law. This solution has aroused doubts and a complaint has been filed against it with the Constitutional Tribunal.

In the current programming period the institutional system of absorption of EU funds allocated for the implementation of cohesion policy has been organized so as to take into account past experience and eliminate mistakes that hinder the absorption process.

A particularly successful measure is the decentralized management of regional operational programmes, delegated to the voivodeship level. Possible improvements at the following stages of systemic changes include: increased participation of the voivodeship local authorities in managing cohesion polices, especially within the scope of aligning the objectives of cohesion policy with regional development strategies, and programming developmental activities together with other local government units and social partners. It is also necessary to simplify the procedures gradually and increase the transparency of project selection system and the system of financial mechanisms operation. 
For purposes related to the process of community projects implementation, Polish local governments are entitled to undertake financial obligations (credits, loans, issuing of securities) to the extent that exceeds the limits specified by the law. These limits are specified in the act on public finances and according to them the amount of debt of a local government unit may not exceed $15 \%$ of its planned revenue. These limitations do not apply for obligations undertaken in connection with the implementation of projects co-financed from EU funds. This solution is to ensure that local governments have better opportunities for rising funds to implement these projects. 


\section{Streszczenie}

Cele polityki regionalnej Unii Europejskiej na okres programowania budżetowego 2007-2013 zostały sprecyzowane w dokumencie pod nazwą "Strategiczne Wytyczne Wspólnoty", przyjętym w formie decyzji Rady z dnia 6 października 2006 r. Dokument ten jest wdrażany w poprzez tzw. Narodowe Strategiczne Ramy Odniesienia (NSFR), przygotowane także przez Polskę jako kraj członkowski, które określają program działań na poziomie narodowym w celu koordynacji wykorzystania środków pochodzących z UE i funduszy krajowych, a przeznaczonych na politykę regionalną.

Referat prezentuje główne elementy składające się na NSFR, m.in. cele, programy operacyjne łącznie ze wskazaniem wysokości środków przeznaczonych na każdy z programów. Jak podkreśla autorka dużą role we wdrażaniu polityki regionalnej odgrywają jednostki samorządu terytorialnego, które odpowiadają za przygotowanie i wdrożenie regionalnych programów operacyjnych. Ponadto wskazuje na przepisy ustawy o finansach publicznych, które regulują sposób wydatkowania środków z pochodzących z UE i przeznaczonych na rozwój regionalny. 